\title{
Studies on the Mechanism of Insulin Resistance after Injury in the Mouse
}

\author{
K. N. Frayn ${ }^{1}$, Y. Le Marchand-Brustel, and P. Freychet \\ Groupe de Recherches sur les Hormones Polypeptidiques et la Physiopathologie Endocrinienne, INSERM U. 145, \\ Faculté de Médecine (Pasteur), Nice, France
}

Summary. Acute insulin resistance developed after scald injury in the mouse. After $2 \mathrm{~h}$ plasma glucose and insulin concentrations were each raised about two-fold. Glucose metabolism was studied in vitro in soleus muscles isolated at this time. Glycolysis and glycogen synthesis, and their stimulation by insulin, were unchanged in muscles from scalded mice, and insulin-stimulated transport of 2-deoxyglucose slightly increased, showing that the insulin resistance seen in vivo is not maintained in isolated tissues. Binding of insulin to liver cell membranes prepared from scalded mice was unaltered, whilst that of glucagon was slightly but significantly reduced, showing that changes in polypeptide-hormone receptors can occur within this short time. It was concluded that the acute loss of sensitivity to insulin after injury does not result from a change in insulin receptor sites and presumably reflects an impairment of glucose metabolism in vivo mediated by circulating hormones.

Key words: Injury, insulin binding, insulin resistance, glucagon binding, muscle.

Loss of sensitivity to insulin is an important clinical problem after injury or major surgery. Identification of the mechanism of this insulin resistance may help in providing a rational basis for the treatment of the injured patient.

Insulin resistance develops acutely after injury in the rat $[1,2]$ and is largely responsible for the impairment of glucose utilization [3] in the injured animal.

\footnotetext{
1 On leave of absence from MRC Trauma Unit, Stopford Building, University of Manchester, Oxford Road, Manchester, England
}

In view of the recent recognition of the role of changes in insulin receptors in modulation of sensitivity to insulin [4], we have investigated the possible involvement of such changes in this acute insulin resistance. For the present studies mice have been used. The metabolic response to injury was found to be similar to that in the rat, and this enabled studies to be made using the recently described [5] isolated mouse soleus muscle preparation.

\section{Materials and Methods}

Mice

Swiss male mice weighing $24-38 \mathrm{~g}$ fed ad libitum were used. For injury they were anaesthetized with ether, the dorsal fur clipped, and a full-thickness scald to $20 \%$ body surface area produced by immersion of the dorsum in water at $83^{\circ} \mathrm{C}$ for $15 \mathrm{sec}$, using a polytetrafluoroethylene (P.T.F.E.) support based on the apparatus described by Arturson [6]. Controls were given a brief period of ether anaesthesia; their fur was not clipped. Animals were then kept at $23^{\circ} \mathrm{C}$ ambient until the time of use, which was $2 \mathrm{~h}$ after injury unless otherwise stated. For blood sampling the mice were anaesthetized with pentobarbitone sodium IP (about $2.8 \mathrm{mg}$ for controls, $1.8 \mathrm{mg}$ for injured), and blood withdrawn from the abdominal aorta into a heparinized syringe and centrifuged at $4^{\circ}$ $\mathrm{C}$; otherwise they were killed by cervical dislocation. Colon temperatures were measured in separate mice with a mercury-in-glass thermometer inserted into the rectum under pentobarbitone anaesthesia; the relatively high heat capacity of the thermometer and the effect of anaesthesia probably led to underestimation of temperatures. 


\section{Soleus Muscle Experiments}

Soleus muscles were isolated as previously described [5] and incubated at $37^{\circ} \mathrm{C}$ in $1.5 \mathrm{ml}$ Krebs-Henseleit bicarbonate buffer [7], $\mathrm{pH} 7.35$, containing defatted bovine serum albumin $(20 \mathrm{~g} / \mathrm{l})$. For measurement of glycolysis and glycogen synthesis all media contained glucose $(5 \mathrm{mmol} / \mathrm{l})$. The muscles were given two preincubations of $15 \mathrm{~min}$ with the requisite insulin concentration present in the second, and then incubated for $60 \mathrm{~min}$ in the presence of $\left[5-{ }^{3} \mathrm{H}\right]$ glucose $(1 \mu \mathrm{Ci} / \mathrm{ml})$ with insulin as required. Separation of the ${ }^{3} \mathrm{H}_{2} \mathrm{O}$ formed in glycolysis and isolation of glycogen for estimation of radioactivity were then carried out as previously described [5]. For measurement of 2-deoxyglucose transport, media contained pyruvate ( $2 \mathrm{mmol} / \mathrm{l})$; muscles were given $15 \mathrm{~min}$ preincubation then $15 \mathrm{~min}$ incubation with 2-deoxyglucose $(1 \mathrm{mmol} / \mathrm{l})$, 2-deoxy-D-[1-14 $\mathrm{C}]$ glucose $(0.2 \mu \mathrm{Ci} / \mathrm{ml})$ and insulin as required, then three $10 \mathrm{~min}$ washes by suspending in $5 \mathrm{ml} \mathrm{NaCl}(0.9 \%)$ on ice before dissolving in $\mathrm{NaOH}(1 \mathrm{~mol} / \mathrm{l})$ for estimation of radioactivity, and protein determination.

Results were expressed as nmol glucose per $\mathrm{mg}$ protein in $60 \mathrm{~min}$ or, for transport, nmol 2-deoxyglucose per $\mathrm{mg}$ protein in $15 \mathrm{~min}$.

\section{Liver Membrane Experiments}

Liver cell membranes were prepared from livers pooled from groups of control and scalded mice [8]. They were frozen in aliquots and stored at $-80^{\circ} \mathrm{C}$. Binding of insulin [9] and of glucagon [10] were determined by incubation at $30^{\circ} \mathrm{C}$ for $1 \mathrm{~h}$ of the resuspended membrane preparation (at a final protein concentration of $0.10-0.15 \mathrm{mg} / \mathrm{ml}$ ) with monoiodohormone $(0.3 \mathrm{ng} / \mathrm{ml})$ and the appropriate concentration of unlabelled hormone. After incubation the membranes were separated by centrifugation, washed as described previously [9], and radioactivity estimated. Measurements were corrected for 'nonspecific' binding of labelled hormone, i. e. that measured in the presence of an excess $(100 \mu \mathrm{g} / \mathrm{ml})$ of unlabelled hormone. This represented $4-5 \%$ of total binding for insulin, and $9-11 \%$ for glucagon, and was identical in the two groups of membranes.

\section{Other Analytical Techniques}

Plasma glucose concentrations were determined with a glucose oxidase method (Boehringer Corporation Ltd.) and plasma insulin concentrations with a charcoal-separation radioimmunoassay [11] using mouse insulin as standard. Protein contents of the muscles or the membrane preparations were determined on aliquots of solutions in $\mathrm{NaOH}(1 \mathrm{~mol} / \mathrm{l})$ by the method of Lowry [12]. Muscle and liver glycogen were determined by ethanol-precipitation in the presence of $\mathrm{Na}_{2} \mathrm{SO}_{4}$ carrier, acid hydrolysis and glucose determination [13].

\section{Reagents}

5- $\left[{ }^{3} \mathrm{H}\right]$ glucose and 2-deoxy-D-[1-14 C $]$ glucose were obtained from the Radiochemical Centre, Amersham, England. Insulin for muscle incubation was diluted from Iletin 80 (Eli Lilly). Porcine monocomponent insulin and porcine glucagon for binding studies, and mouse insulin standard for radioimmunoassay, were gifts from J. Schlichtkrull (Novo Research Institute, Copenhagen, Denmark) and G. Jouve (Novo Paris, France). Monoiodinated insulin and glucagon were prepared as previously described $[9,14]$.

\section{Statistical}

Statistical methods were those described by Snedecor and Cochran [15]. Significance of differences was calculated using the $t$-test modified when necessary for samples of unequal variance. Results are expressed as means \pm SEM (n) except for plasma insulin concentrations (Table 2). These appeared, in injured animals, to be log-normally distributed in that significant skewness $(P<0.02)$ present in their distribution was almost completely removed on transformation to logarithms, and they are therefore shown as geometric means.

\section{Results}

\section{General Response to Injury}

Three out of 16 mice died acutely from the injury, all at about $24 \mathrm{~h}$. This makes the injury more severe than a $20 \%$ scald in the rat, which is non-lethal [2]. There was considerable hyperglycaemia by $1 \mathrm{~h}$ after the injury, tending to decline by $4 \mathrm{~h}$ (Table 1). After $24 \mathrm{~h}$ in surviving mice there was a significantly lower plasma glucose than in controls (controls $9.2 \pm 0.3$ (4), scalded $8.0 \pm 0.2(13) \mathrm{mmol} / \mathrm{l} ; \mathbf{P}<0.01)$ presumably related to a lower food intake in the injured.

All other studies were made at $2 \mathrm{~h}$ after injury (Table 2). At this time there was hyperinsulinaemia, a decrease in liver glycogen, a tendency to a reduction in muscle glycogen (soleus) and a fall in core temperature, responses almost identical to those seen in the rat after similar injury $[1,2]$. There was a negative correlation amongst the scalded mice be- 
Table 1. Time-course of hyperglycaemia after dorsal scald injury in the mouse

\begin{tabular}{llllll}
\hline $\begin{array}{l}\text { Time (h) } \\
\begin{array}{l}\text { Plasma glucose } \\
(\mathrm{mmol} / \mathrm{l})\end{array}\end{array}$ & Controls & 1 & 2 & 3 & 4 \\
\hline
\end{tabular}

$\mathrm{n}=5$ in each group

Table 2. Responses $2 \mathrm{~h}$ after dorsal scald injury in the mouse

\begin{tabular}{|c|c|c|c|}
\hline & Controls & Scalded & $\mathbf{P}$ \\
\hline $\begin{array}{l}\text { Plasma glucose } \\
(\mathrm{mmol} / \mathrm{l})\end{array}$ & $11.3 \pm 0.2(28)$ & $21.6 \pm 1.2(27)$ & $<0.001$ \\
\hline $\begin{array}{l}\text { Plasma insulin } \\
\text { (ng/ml) }\end{array}$ & $\begin{array}{c}2.0(27) \\
1.8-2.2\end{array}$ & $\begin{array}{l}4.6(25) \\
4.1-5.2\end{array}$ & $<0.001$ \\
\hline $\begin{array}{l}\text { Liver glycogen } \\
\text { ( } \mu \mathrm{g} / \mathrm{mg} \text { wet wt.) } \\
\text { Muscle glycogen } \\
\text { ( } \mu \mathrm{g} / \mathrm{mg} \text { protein) }\end{array}$ & $37 \pm 3(8)$ & $21 \pm 3(8)$ & $<0.005$ \\
\hline $\begin{array}{l}\text { Before } \\
\text { After }\end{array}$ & $\begin{array}{l}19 \pm 3(8) \\
18 \pm 2(8)\end{array}$ & $\begin{array}{l}13 \pm 2(8) \\
16 \pm 2(8)\end{array}$ & $\begin{array}{l}\text { N.S. } \\
\text { N.S. }\end{array}$ \\
\hline $\begin{array}{l}\text { Temperature } \\
\left({ }^{\circ} \mathrm{C}\right)\end{array}$ & $36.9 \pm 0.3(8)$ & $30.5 \pm 0.4(6)$ & $<0.001$ \\
\hline
\end{tabular}

For plasma glucose and insulin estimations and for colon temperature measurement mice were anaesthetized with pentobarbitone. Soleus muscle glycogen was estimated either directly after isolation of the muscle, about 2 min after killing the animal ('Before'), or after two preincubations of $15 \mathrm{~min}$ each with glucose $(5 \mathrm{mmol} / \mathrm{l})$ but in the absence of insulin ('After'). Plasma insulin concentrations, for reasons given in the text, are given as a geometric mean with standard error range underneath

tween plasma concentrations of glucose and insulin (Fig. 1). The product of plasma glucose $(\mathrm{mmol} / \mathrm{l})$ and insulin $(\mathrm{ng} / \mathrm{ml})$ concentrations, which in the small animal, for a given rate of glucose turnover, may be taken as a measure of insulin resistance [16] was nevertheless considerably elevated (means \pm SEM; controls $25 \pm 2$, scalded $111 \pm 12$ ) with little overlap in individual values between the groups (Wilcoxon test; $\mathrm{P}<0.0001)$.

\section{Glucose Metabolism in the Isolated Soleus Muscle}

In two separate experiments no differences were found between muscles from control or scalded mice in glycolysis or in glycogen synthesis, measured with $\left[5-{ }^{3} \mathrm{H}\right]$ glucose, nor in their responses to insulin added in vitro (Table 3). Although an initial difference in glycogen content might complicate interpretation of these results, muscle glycogen measured in muscles after the two preincubations (without insulin) was not significantly different (Table 2 ) comparing muscles from control and scalded mice.

$\left[{ }^{14} \mathrm{C}\right] 2$-deoxyglucose accumulation, a measure of glucose transport and phosphorylation, was studied since this measurement is made more rapidly and
Table 3. Glucose transport and metabolism in soleus muscles isolated from control and scalded mice

\begin{tabular}{llll}
\hline Insulin $(\mu \mathrm{U} / \mathrm{ml})$ & 0 & 100 & 1000 \\
\hline Glycolysis & & & \\
$\quad$ Controls & $42 \pm 3$ & $65 \pm 7$ & $66 \pm 3$ \\
$\quad$ Scalded & $43 \pm 5$ & $54 \pm 8$ & $71 \pm 7$ \\
Glycogenesis & & & \\
$\quad$ Controls & $1.7 \pm 0.4$ & $7.9 \pm 1.9$ & $13.3 \pm 1.2$ \\
$\quad$ Scalded & $2.1 \pm 0.7$ & $6.5 \pm 0.9$ & $14.7 \pm 1.4$ \\
Transport & & & \\
$\quad$ Controls & $2.7 \pm 0.2$ & $4.5 \pm 0.5$ & $8.1 \pm 0.4$ \\
$\quad$ Scalded & $2.8 \pm 0.3$ & $6.4 \pm 0.4^{\mathrm{a}}$ & $9.9 \pm 0.7^{\mathrm{b}}$ \\
\hline
\end{tabular}

Methods and units are described in the text. Transport refers to accumulation of 2-deoxyglucose. In each case results from one experiment are shown; all experiments were repeated and gave similar trends. $n=5-6$ in each group

Difference from controls: ${ }^{a} \quad P<0.02 ;{ }^{b} \quad P<0.05$

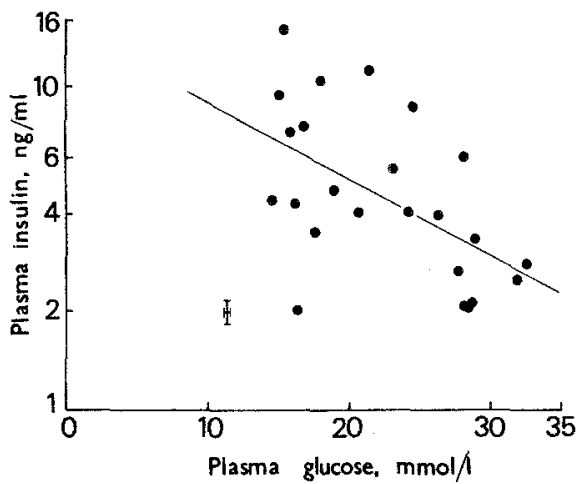

Fig. 1. Plasma glucose and insulin concentrations in scalded and control mice. Mice were bled under pentobarbitone anaesthesia at $2 \mathrm{~h}$ after injury. Insulin is plotted on a logarithmic scale for reasons given in the text. Points show results in scalded mice $(n=24)$ with the line of least mean squares best fit. The negative correlation is significant $(\mathrm{r}=0.55, \mathrm{P}<0.01)$. Results in controls are shown as arithmetic mean \pm SEM (glucose), geometric mean with SE range (insulin), and are taken from Table 2

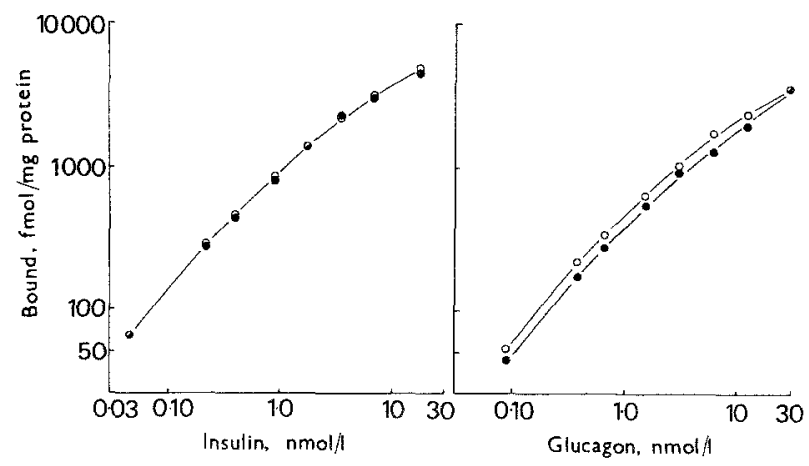

Fig. 2. Binding of insulin and glucagon by liver membranes from control and scalded mice. Binding was determined as described in the text. For insulin the results are means of two separate experiments, and for glucagon are from one experiment with duplicates at each point and quadruplicates at the lowest concentration (no unlabelled hormone). Replicates were in all cases too close to show separately. $O$, controls; 9 , scalded 
might thus reflect more closely any inhibition in vivo. Although basal (without addition of insulin) transport was unchanged, insulin-stimulated transport was actually significantly greater in muscles from scalded mice (Table 3).

\section{Insulin and Glucagon Binding to Liver Membranes}

Binding of insulin to liver membranes was not different in membranes from control and scalded mice (Fig. 2). Binding of glucagon, however, was found to be slightly reduced (Fig. 2). The mean decrease in glucagon binding at the lowest concentration tested $(0.09 \mathrm{nmol} / \mathrm{l})$ was $15 \%(\mathrm{P}<0.02, t$-test $)$. This was confirmed in two further separate experiments. The tendency of the curves to converge at higher concentrations suggests that the decrease was due to a difference in affinity rather than to a change in the number of receptor sites.

\section{Discussion}

The general characteristics of the response to injury in the mouse show that it is similar in most respects to that seen in the rat. However, the negative correlation found between plasma concentrations of insulin and glucose (Fig. 1) suggests that unlike in the rat [1, 17] the hyperglycaemia after injury in the mouse may be increased owing to some variable suppression of the insulin response, as occurs in man (see [1] for references). Despite this suppression both plasma glucose and insulin concentrations were considerably elevated compared with controls. It is probable, from the similarity with the rat [3] as well as from the fall in core temperature (glucose turnover being related, in the small mammal, to whole-body heat production $[3,16])$, that these increases were not associated with any increase in the rate of glucose utilization in vivo. This period shortly after injury in the mouse is therefore characterized, as in the rat $[1,2]$, by a considerable loss of sensitivity to insulin in vivo. Skeletal muscle is the major site of insulin-stimulated glucose utilization, and hence presumably the major tissue involved in the insulin resistance, in such a state.

It was therefore interesting that no impairment of insulin-stimulation of glucose transport, glycolysis or glycogen synthesis was found in the muscles from the scalded mice, suggesting that no change of a structural nature had occurred. In chronic hyperinsulinaemic states the number of insulin receptors is decreased in muscle $[18,19]$ and other tissues $[20$, $21]$ and such changes are associated with a decreased sensitivity to insulin in vitro [19]. The unchanged binding of insulin to the liver membranes prepared from the scalded mice lends further support to a lack of change of the insulin receptor state in vivo. The slight decrease in glucagon binding observed in the liver membranes from the scalded mice shows, however, that changes in polypeptide-hormone receptors, albeit small, can occur and are detectable in such an acute state. This decrease is unlikely to be of any functional significance as, in the rat, very high plasma glucagon concentrations have been found in the portal vein shortly after injury (often $>1 \mathrm{ng} / \mathrm{ml}$; K. N. Frayn, H. B. Stoner \& K. J. O'Connor, unpublished), and hepatic glycogenolysis is rapid after injury [1, 22; Table 2].

The lack of maintenance in isolated tissues of the insulin resistance seen in vivo contrasts with the findings of Chaudry, Sayeed and Baue [23, 24, 25], showing a decreased sensitivity to insulin-stimulation of glucose uptake in soleus muscles isolated from rats in haemorrhagic shock. The difference probably reflects the differences between these forms of injury. After a $20 \%$ scald injury there is only a small fall in blood pressure (in the rat to about $12 \mathrm{kPa}$; R.A. Little, unpublished) and no evidence of any general failure of oxygen transport [26]. In haemorrhagic shock, however, there may be considerably diminished perfusion of skeletal muscle [27], and Chaudry et al. [28] have shown that ATP levels are low in the muscles from their animals. In the case of scald injury it seems probable from the present results that the insulin resistance seen in vivo is mediated by other circulating hormones, and presumably by an intracellular impairment of glucose metabolism, as has been suggested from measurement of intracellular glucose concentrations in muscle in vivo [29]. (No hormones other than insulin were measured in the present studies.) It might, for example, be associated with an increased breakdown of muscle triglycerides, leading to an impairment of glycolysis $[30,31]$. The present experiments with 2-deoxyglucose lend some support to this hypothesis. If the muscles from the injured mice began the study with a reduced triglyceride content there may have been less fat oxidation in vitro and thus a lessening of the 'tonic' control of hexokinase by glucose 6-phosphate [32], accounting for the greater insulin-stimulation of 2-deoxyglucose uptake observed in these muscles. Elucidation of this intracellular impairment of metabolism requires further study.

Acknowledgements. We would like to thank Mme. N. GrenierBrossette for technical assistance and Miss P.F. Maycock for constructing the scalding apparatus. K.N.F. was the recipient of an INSERM-Ciba Foundation Anglo-French Medical Exchange Bursary, and thanks the Medical Research Council for granting leave of absence during the period of these studies. This work was supported in part by Grant A.T.P. 38.76 .70 of the Institut 
National de la Santé et de la Recherche Médicale (France), and Grant 75.7.1366 from the Délégation Générale à la Recherche Scientifique et Technique (France).

\section{Reference}

1. Frayn, K. N.: Effects of burn injury on insulin secretion and on sensitivity to insulin in the rat in vivo. Eur. J. Clin. Invest. 5, 331-337 (1975)

2. Frayn, K. N.: Insulin secretion after injuries of differing severity in the rat. Br. J. Exp. Pathol. 57, 316-320 (1976)

3. Heath, D. F., Corney, P. L.: The effects of starvation, environmental temperature and injury on the rate of disposal of glucose by the rat. Biochem. J. 136, 519-530 (1973)

4. Olefsky, J.M.: The insulin receptor: its role in insulin resistance of obesity and diabetes. Diabetes 25, 1154-1165 (1976)

5. Cuendet, G.S., Loten, E. G., Jeanrenaud, B., Renold, A. E.: Decreased basal, non-insulin stimulated glucose uptake and metabolism by skeletal soleus muscle isolated from obesehyperglycemic (ob/ob) mice. J. Clin. Invest. 58, 1078-1088 (1976)

6. Arturson, G.: Pathophysiological aspects of the burn syndrome. Acta Chir. Scand. [Suppl.] 274 (1961)

7. Dawson, R.M.C., Elliott, D.C., Elliott, W.H., Jones, K.M. (eds.): Data for biochemical research, 2nd edition, p. 507. Oxford: Clarendon Press 1969

8. Neville, D.M.: Isolation of an organ specific protein antigen from cell-surface membrane of rat liver. Biochim. Biophys. Acta 154, 540-552 (1968)

9. Freychet, P.: The interactions of proinsulin with insulin receptors on the plasma membrane of the liver. J. Clin. Invest. 54, 1020-1031 (1974)

10. Bataille, D., Freychet, P., Rosselin, G.: Interactions of glucagon, gut glucagon, vasoactive intestinal polypeptide and secretin with liver and fat cell plasma membranes: binding to specific sites and stimulation of adenylate cyclase. Endocrinology 95, 713-721 (1974)

11. Herbert, V., Lau, K.-S., Gottleib, C.W., Bleicher, S. J.: Coated charcoal immunoassay of insulin. J. Clin. Endocrinol. Metab. 25, 1375-1384 (1965)

12. Lowry, O.H., Rosebrough, N.J., Farr, A.L., Randall, R.J.: Protein measurement with the Folin phenol reagent. J. Biol. Chem. 193, 265-275 (1951)

13. Good, C. A., Kramer, H., Somogyi, M.: The determination of glycogen. J. Biol. Chem. 100, 485-491 (1933)

14. Nottley, J.-J., Rosselin, G.: Monoiodoglucagon: préparation, isolement, identification, contrôle radio-immunologique. C. R. Acad. Sci. [D] (Paris) 273, 2118-2121 (1971)

15. Snedecor, G. W., Cochran, W. G.: Statistical methods, 6th edition. Ames: Iowa State University Press 1967

16. Heath, D.F., Frayn, K. N., Rose, J. G.: Rates of glucose utilization and glucogenesis in rats in the basal state induced by halothane anaesthesia. Biochem. J. 162, 643-651 (1977)

17. Frayn, K. N.: Effects of metformin on insulin resistance after injury in the rat. Diabetologia 12, 53-60 (1976)

18. Olefsky, J., Bacon, V.C., Baur, S.: Insulin receptors of skeletal muscle: specific insulin binding sites and demonstration of decreased numbers of sites in obese rats. Metabolism 25, 179-191 (1976)
19. Le Marchand-Brustel, Y., Jeanrenaud, B., Freychet, P.: Insulin binding and effects in the isolated soleus muscle of lean and obese mice. Am. J. Physiol. (In Press)

20. Soll, A.H., Kahn, C. R., Neville, D.M. Jr., Roth, J.: Insulin receptor deficiency in genetic and acquired obesity. J. Clin. Invest. 56, 769-780 (1975)

21. Le Marchand, Y., Loten, E. G., Assimocopoulos-Jeannet, F., Forgue, M. E., Freychet, P., Jeanrenaud, B.: Effect of fasting and streptozotocin in the obese-hyperglycemic (ob/ob) mouse: apparent lack of a direct relationship between insulin binding and insulin effects. Diabetes 26, 582-590 (1977)

22. Heath, D.F.: Liver metabolism after injury. In: A.G.B. Kovách, H. B. Stoner, J. J. Spitzer (eds.): Neurohumoral and metabolic aspects of injury, pp. 271-276. New York: Plenum Press 1973

23. Chaudry, I.H., Sayeed, M.M., Baue, A. E.: Insulin resistance in experimental shock. Arch. Surg. 109, 412-415 (1974)

24. Chaudry, I. H., Sayeed, M. M., Baue, A. E.: The effect of insulin on glucose uptake in soleus muscle during hemorrhagic shock. Can. J. Physiol. Pharmacol. 53, 67-73 (1975)

25. Chaudry, I. H., Sayeed, M. M., Baue, A. E.: Insulin resistance and its reversal by in vivo infusion of ATP in hemorrhagic shock. Can. J. Physiol. Pharmacol. 54, 736-741 (1976)

26. Little, R. A., Threlfall, C. J.: Effect of nonhemorrhagic injury on blood acid-base status, erythrocyte 2,3-diphosphoglycerate concentrations, and hemoglobin-oxygen affinity. Circulatory Shock 1, 209-216 (1974)

27. Appelgren, L.: Perfusion and diffusion in shock. A study of disturbed tissue-blood exchange in low flow states in canine skeletal muscle by a local clearance technique. Acta Physiol. Scand. [Suppl.] 378, 1-72 (1972)

28. Chaudry, I.H., Sayeed, M.M., Baue, A. E.: Effect of hemorrhagic shock on tissue adenine nucleotides in conscious rats. Can. J. Physiol. Pharmacol. 52, 131-137 (1974)

29. Frayn, K.N.: The site of insulin resistance after injury. Endocrinology 101, 312-314 (1977)

30. Randle, P.J., Newsholme, E. A., Garland, P. B.: Regulation of glucose uptake by muscle. 8 . Effects of fatty acids, ketone bodies and pyruvate, and of alloxan-diabetes and starvation, on the uptake and metabolic fate of glucose in rat heart and diaphragm muscles. Biochem. J. 93, 652-665 (1964)

31. Randle, P. J., Garland, P. B., Hales, C. N., Newsholme, E. A., Denton, R. M., Pogson, C. I.: Interactions of metabolism and the physiological role of insulin. Recent Prog. Horm. Res. 22, 1-48 (1966)

32. Lueck, J.D., Fromm, H. J.: Kinetics, mechanism and regulation of rat skeletal muscle hexokinase. J. Biol. Chem. 249, 1341-1347 (1974)

Received: September 13, 1977,

and in revised form: January 13,1978

K. N. Frayn, Ph. D.

MRC Trauma Unit

Stopford Building

University of Manchester

Oxford Road

Manchester M13 9PT

England 